\title{
The Homework of Response-Ability in Science Education
}

The purpose of this chapter ${ }^{1}$ is to introduce response-ability as a concept and practice to (re)open science education's understanding and enactments of responsibility towards Indigenous ways-of-living-with-nature (IWLN) and traditional ecological knowledge (TEK). This is significant as even well-intentioned forms of responsibility are often and inadvertently overcoded by the (neo-)colonial logics that it sets out to refuse and resist: responsibility and the ability to respond are often not one and the same. Within this chapter, I revisit a significant personal pedagogical encounter in which this distinction made itself felt and known. Thinking with the work of Sami scholar Rauna Kuokkanen, this narrative provides a platform to explore practices of epistemic ignorance and its (co)constitutive relation to knowledge, as well as what she refers to as "the homework of response-ability" required to (re)open the norms of responsiveness towards the possibility of heeding the call of Indigenous science from within the structure of science education. Concluding thoughts underscore the promise of deconstruction (rather than destruction) ${ }^{2}$ as a theoretical, methodological, and ethical tool to resist the (fore)closure of responsibility towards hospitably receiving Indigenous science on its own terms.

M. Higgins, Unsettling Responsibility in Science Education, Palgrave Studies in Educational Futures, https://doi.org/10.1007/978-3-030-61299-3_2 


\section{PrEAMble: ReSPONSIBILITY and De/Colonizing Science Education}

There is no single, simple, exhaustive answer to the complex question of how we can know the "other" .... We must redefine the problem not in terms of knowing the "other" but in terms of learning to "see" the existence of epistemes [ways-of-knowing] that have long been rendered invisible. We need to redefine the question in terms of a convergence of epistemes. (Kuokkanen, 2007, p. 120)

As explored in the previous chapter, "there is no single, simple, exhaustive answer to the complex question of how we can know the 'other'" (Kuokkanen, 2007, p. 120) in (and importantly of ) science education. This is in part because even when Indigenous science (see Cajete, 2000) is included within school science, rather than excluded, it is often ways that differ from or defer its intended meanings. Differentially, each exclusion or problematic inclusion enacts (partial) dialectic negations of Indigenous science by sublating, subsuming, or suturing over it. "We must redefine the problem not in terms of knowing the 'other' but in terms of learning to 'see' the existence of epistemes [ways-of-knowing] that have long been rendered invisible" (Kuokkanen, 2007, p. 120) as the very framing of the problem is not without consequence. For Indigenous, diasporic, and other post-colonial students, such school science regularly produces experiences of cultural assimilation and acculturation rather than enculturation. In other words, rather than a harmonious interfacing of cultures (i.e., enculturation), encounters of school science are more likely to house potential for dialectical negation that is either actualized (i.e., assimilation) or remains un-actualized through students' complex and complicated curricular navigation (i.e., acculturation). For these students whose daily lived experiences continue to be negatively impacted by colonial logics (e.g., Eurocentrism), this manifests as a form of epistemic violence. Here, as mentioned within the previous chapter, science education and educators have a responsibility for which there are but only alibis for turning away.

However, in thinking with Sami scholar Rauna Kuokkanen (2007), whose scholarship centres Western modern educational and institutional responsibility towards Indigenous ways-of-knowing and ways-of-being, it is not sufficient to take up this responsibility: "We need to redefine the 
question" (p. 120) of responsibility itself. As stated above, and simply put, we need responsible ways to be responsible: science education cannot be responsible towards Indigenous science if it cannot perceive it and be responsible for the ways in which it has and continues to render it invisible. For there to be responsibility, there must be an ability to respond: how we (re)define and approach the question of IWLN in science education matters, in both senses of the word (i.e., matters and materializes).

As an emergent scholar pursuing unsettling science education and aspiring ally, the primary orientation that guides my efforts is ethically heeding the call of Indigenous science (e.g., traditional ecological knowledge [TEK], Indigenous ways-of-living-with-Nature [IWLN]). I continue to wrestle with the question: How is Indigenous science to-come with/in the context of science education? As Tewa scholar Gregory Cajete (2000) explains, Indigenous science displays and has, since time immemorial, always deployed "ingenuity, creativity, resourcefulness, and ability of people to learn and to teach a harmonious way of existence with Nature" (p. 78). Accordingly, the guiding question I pose is not intended to signal a science yet-to-exist. Rather, to-come calls on both the ways in which Indigenous science has not yet (wholly) arrived within the context of science education, as well as a responsibility of hospitality towards that which is to-come. If science education is to hospitably receive Indigenous science, it must address the ways in which its structures-the assumptions, terms, modes of organization, practices, and beliefs-contribute to exclusion of Indigenous science, as well as inclusion that disciplines, differs from, and defers Indigenous science (to-come). Equally significant is the exploration of the following: how can the culture of the discipline of science education be (re)opened and re(con)figured to receive Indigenous science to-come, on its own terms, and in ethical velation? Importantly, when that which is to-come (here, Indigenous science) is never (fully) knowable within and distorted by the current frames of science education, what modes, practices, and enactments of responsibility are available? Lastly, how must responsibility be unsettled (i.e., decolonized and deconstructed) in order to (re) open the space of responsiveness?

Significantly, in unsettling responsibility, it is important to understand the ways in which responsibility can be at once taken-for-granted (i.e., settled) and (re)produced through (neo-)colonial logics (i.e., settling). With such a double(d) understanding in mind, Kuokkanen (2007) quickly 
describes the conventional and (neo-)colonial concept of responsibility as such:

Western liberal notions of responsibility are often constructed as a social Darwinist "burden of the fittest," with the benevolent imperialist self-cast as "helping" those less fortunate (read "privileged"). In this discourse, responsibility becomes nothing more than a duty... [producing] a hierarchy in which the "helper" enjoys moral superiority, which often manifests itself as a patronizing attitudes and practices. (p. 41)

Responsibility, at least as such, cannot and does not account for the ways in which the subject of responsibility might always already be in Indigenous-Western relations and the ways in which Western subjects already have responsibility in the juridical sense. ${ }^{3}$ Further, it doubly individualizes responsibility, making responsibility an individual affair and rendering the individual the adjudicator of responsible action (e.g., "if an individual [educator] consciously believes that she or he is not racist, that is the end of the issue for that person and the end of her or his responsibility" [Kuokkanen, 2007, p. 63]).

Elsewhere (Higgins, 2014), I have begun asking similar questions of the relationship between responsibility and the (in)ability to respond within educational research: asking questions of response-ability (see also Higgins, 2017). This earlier exploration began exposing and troubling the ways in which I attempted ${ }^{4}$ to account for and be accountable to Indigeneity (e.g., IWLN) from within (naturalized and normalized) (neo-)colonial discourses (e.g., Eurocentrism, whiteness), even though I was actively working against this power differential (see also Higgins, Madden, \& Korteweg, 2015). Stated otherwise, as the result of a (neo-)colonial curriculum that is hidden in plain sight (see Battiste, Bell, Findlay, Findlay, \& Henderson, 2005), efforts to work against and beyond (neo-)colonial categories, concepts, and structures often come to reify that which is laboured against; decolonizing approaches may come to be $\mathrm{de} /$ colonizing. In a nutshell,

De/colonizing underscores the complexity of the material-discursive structures, commitments, and practices of educational institutions and the Indigenizing initiatives they pursue. It suggests that decolonization need not be (and conceivably cannot be) constructed in neat opposition to colonization, and calls for consistent examination of colonial logics and productions that seep into hybrid colonizing and decolonizing contexts. (Higgins \& Madden, 2017, p. 35) 
To take seriously de/colonizing is to be hyper-vigilant of the ways in which colonial logics and productions seep (even) into decolonizing efforts (see also Madden \& McGregor, 2013). This, as Lyn Carter (2004, 2010) and Ali Sammel (2009) point out, is much needed in spaces of science education.

Within this chapter, I "begin" this exploration herein with a focus on the relationship between response-ability and my own practice as de/colonizing science educator through a narrative of a significant personal pedagogical encounter in which the distinction between responsibility and the ability to respond made itself felt and known.

\section{Encountering the Subtle Yet Important Difference BetweEn Response-AbILITY AND Responsibility in MY De/Colonizing Science Education Practice}

Because we need to "begin" some-where and some-time, let's "begin" in Iqaluit, Nunavut in July of $2009 .^{5}$ At the time of authoring this book, the narrative I am about to tell is one that dates about ten years. However, it is one that I continue to heed as it continues to bear relevance on how I understand myself in relation to responsibility and the in/ability to respond. During the summer of 2009, I was delivering curriculum that I developed that engaged Indigenous (here, Inuit) and non-Indigenous youth in exploring, constructing, and documenting differential cultural constructions of science (i.e., ways-ofknowing-Nature) through participant-driven videography in their home community of Iqualuit, Nunavut. As my first major research project towards decolonizing science education (see Higgins, 2014), I was poised to learn a difficult lesson about the distinction between ability and willingness that Kuokkanen (2007) presents in how she defines response-ability: "an ability to respond, to respond to the world beyond oneself, as well as a willingness to recognize its existence" (p. 39). But then again, "decolonization ... is not as straightforward a strategy as it first seems" (p. 144). My willingness, intentionality, or desire to recognize the otherness that is Indigenous science (in relation to science education) was not sufficient in and of itself. But I am getting ahead of myself here.

Through this work, I took up the important call to decolonize science education through what Mi'kmaq scholar Marie Battiste (2013) describes as the "two-prong process" of decolonizing education. It simultaneously and iteratively entails deconstruction of (neo-)colonial structures and 
strategies, and reconstruction that centres and takes seriously Indigenous, diasporic, and other post-colonial ways-of-knowing and ways-of-being towards reshaping the place-based processes and priorities of education and educational research. Both prongs are of significance given my positionality as a white, male, fourth-generation Euro-settler of Irish and Scottish descent who is working to honour my ever-shifting relationships as a science educator working with/in diverse First Nations, Métis, and Inuit communities.

Responding to the first prong (i.e., deconstruction), I engaged in examining and challenging the ways in which Eurocentrism-a pervasive discursive force that (re)centres Western modern(ist) culture, people, places, and histories as the normative standard against which other waysof-knowing are judged, usually as lesser and deficient (Battiste, 2005)works to maintain the status quo. This was done through working to disrupt the concepts and categories that tend to create, and are utilized to uphold, inequality within science education, as well as the systems under which these inequalities become possible (e.g., "what counts" as science in science education and its entangled apparatus of norms; see Chapters 3-6). This process largely involved engaging in critical self-reflexive questioning, responding to queries such as:

How does my Western training in the world of science (i.e., in physics) differentially produce my conceptions of the nature of science, what it is, what it is perceived as, and what it can be? How do I work against the problematic foreclosure of such knowledge in order to maintain pedagogical flexibility? How do I work within and against the implicit Eurocentric notions of validity, empirical worth, and instrumentality that I have received in order to make space for Indigenous knowledges? (Higgins, 2014 , p. 163)

In engaging in the second prong of decolonizing education (i.e., reconstruction), students were collaboratively involved in creatively juxtaposing Western modern science (WMS) and Inuit Qaujimajatuqangit (i.e., Inuit traditional knowledge) to reveal, (re)structure, and (re)direct the multiple ways that the gaze of dominance is maintained. For example, this gave youth an agentic role in resisting problematic constructions of Indigeneity with respect to ways-of-knowing-Nature (e.g., science). This participantdirected videography took various shapes, notably documentary-style 
interviews with diversely positioned community members (e.g., traditional knowledge holders, health practitioners, environmental scientists), alongside their own short movies that were a form of digital storytelling.

Despite well-laid plans, in attempting to put to work a decolonizing sensibility and taking up responsibility (both that of pedagogy and educational research), there were nonetheless ways in which I was not able to respond. This subtle but importance differentiation between responsibility and response-ability manifested most noticeably though my self-reflexive work around the youth's engagement in digital storytelling (see Higgins, 2014). While my research was originally planned around youth engaging in documentary film, early on the youth made it clear (through scrunched brows, an Inuit way of saying no) that they did not wish to only make movies about their perception of science during what was, for them, a STEM summer camp. Cognizant of the multiple gradients of power across which dissent was being articulated, as well as the ongoing problematic research relationships between research institutions and Indigenous communities (see Battiste, 2013), I knew I would have to "let go" of the research project as designed.

While the youth agreed to participate in interviewing community members around ways-of-knowing-Nature, we negotiated that the youth would primarily engage in digital storytelling practices as their major project to share with parents and community members by the end of the programme. As an emerging decolonizing educator, I recognized the importance of respecting learners' choices. However, as a budding science education researcher, it was difficult to shift away from a focus I had been developing (i.e., exploring cross-cultural ways-of-knowing-Nature). Because youth were spending less time accessing those who "know" about and with Nature (e.g., traditional knowledge holders, health practitioners, environmental scientists), I had trouble conceptualizing the youth's storytelling practices as enacting ways-of-knowing-Nature. This dissonance was perhaps most heightened when some of the youth explored Oreo eating Olympics as a central story topic! In this sense, I was not able to take up responsibility much beyond the ways the ways in which I had conceived of prior the research; there were ways in which I was not able to respond.

Significantly, plugging Indigenous metaphysics into an educational framework organized by a Western modern metaphysics resulted in excesses that were far too often sutured over, subsumed, and/or sublated by an approach to knowing and being with nature that could not account for Indigenous ways-of-knowing-in-being's excesses. ${ }^{6}$ Specifically, I had 
come to the research with the settled, Western modern scientific assumption that science is strictly a human, epistemological affair (see Barad, 2007; Cajete, 2000). Because of the ways this dialectic negation operates, as a result, I was blind(ed) to the ways in which some of the digital storytelling practices that youth engaged in (e.g., (re)telling of traditional story of Mubaha, the aptly named traditional Inuit monster who chases after children to tickle them to death with his long claws) were not simply stories about place but were told with place (i.e., having and being had by an Indigenous "sense of place"; see Cajete, 1994, 2000). In the videos, place makes itself intelligible through the beings that come to (co-)constitute the ecology of relationships that make the eastern arctic a beautiful, yet dangerous place if not respected on its own terms. Their stories "starred" an ecology of relationships with which Inuit peoples have developed ways-of-knowing-in-being premised on Nature's flux and processes, deeply guided with and through relational ethics, as well as practices of regeneration. The stories were never the students' (and the humans they worked with) alone (despite the frames brought to the viewing); the natural world always makes itself intelligible and participates in the construction of knowledge about itself, whether we acknowledge it or not (see Cajete, 1994, 2000).

Elsewhere (Higgins, 2014), I stated that the decolonizing curriculum (e.g., border crossing) and pedagogies (e.g., culture broker) available to me worked both within and against a problematic centre. As such, curriculum, pedagogy, and pedagogue were exceeded in pedagogical practice by the very coloniality the approach worked against, thus becoming de/colonizing: pedagogical slippage occurred. Here, thinking with Kuokkanen (2007), coloniality overcoded the ability to respond, making me unable to (fully) take up the responsibility of heeding the call of Indigenous science. Specifically, I could not (wholly) respond to the natural world and Indigenous-ways-of-living-with-Nature because I could not recognize its existence (beyond that which made itself intelligible within my frames). I could not responsibly heed the call of Indigenous science because I could not hear the call as such. Again, a willingness to recognize the otherness that is Indigenous science is not sufficient ${ }^{7}$; it is specifically for this reason that Kuokkanen (2007) suggests that response-ability entails addressing epistemic ignorance. 


\section{Epistemic Ignorance And/In Science Education}

Kuokkanen (2010) states, "if knowledge is a prerequisite for responsibility, ignorance presents a serious threat to responsible, response-able behaviour and thinking" (p. 64). Yet, as illuminated by my desire to recognize the existence of Indigenous science from within a Western modern(ist) episteme, working to know Indigenous-way-of-living-withNature from such a perspective is also a project that is fraught. As Kuokkanen (2008) suggests, the relation between knowledge and ignorance is not so linear or dichotomous; not knowing is not necessarily an absence of knowledge, but can also be the result of knowledge. ${ }^{8}$ Kuokkanen (2008) refers to this knowledge-as-ignorance, as well as traces the discursive forces and flows through which it emerges as epistemic ignorance:

Epistemic ignorance refers to ways in which academic theories and practices ignore, marginalize and exclude other than dominant Western European epistemic and intellectual traditions. These "other" epistemic and intellectual traditions are foreclosed in the process of producing, reproducing and disseminating knowledge to an extent that generally there is very little recognition and understanding of them. Epistemic ignorance is thus not limited to merely not-knowing or lack of understanding. It also refers to practices and discourses that actively foreclose other than dominant epistemes and refuse to seriously contemplate their existence. Epistemic ignorance is thereby a form of subtle violence. (p. 63)

As Michiel van Eijck and Wolff-Michael Roth (2007) underscore, this is certainly the case in science education regarding the relationship between WMS, TEK, and IWLN. Drawing on Michel Foucault, they explain that the logics of science education can often be characterized as a "regime of truth". Regimes of truth are marked by circular relations: each "truth" is but a differential articulation of the systems of power that produces it, whose articulation in turn (re)produces the systems of power. Such a circular relation can be read in two ways: first, as the capillary circulation of power from one conceptual node to another; and second, signaling a (quasi-)hermetic circle, a (fore)closure of knowledge.

Foreclosure, as post-colonial scholar Gayatri Spivak (1999) utilizes it, signals instantiated pre-emergence of meaning. It indicates the ways in which the language we possess also possesses us. It is when the knowledge shapes how we intake experience, preventing experiences of otherness to 
be anything more than what can already be known within the already existing, and rigidified, circular relations of closure. In other words, how what we know acts as barrier to engaging with what we do not; a form of closure that is a priori to meaning-making.

The foreclosure resulting from epistemic ignorance is of particular relevance considering the ways in which IWLN and TEK are often only considered science when they fit the criteria of "valid" science (which often happens to be that of WMS). Or, as Kuokkanen (2008) summarizes, the foreclosure resulting from epistemic ignorance makes it such that "Indigenous people 'cannot speak'; that is, when they speak from the framework of their own epistemic conventions, they are not heard or understood by the academy" (p. 60). As mentioned within the previous chapter, after Ngāti Kahungunu ki Wairarapa and Ngāi Tahu scholar and science educator Liz McKinley (2007), the ways in which Indigenous science can be articulated in relation to WMS maps onto four general categories: (a) where Indigenous science can be explained within WMS; (b) where Indigenous science could be explained through WMS, but the explanation has yet to be developed; (c) where there is a link between Indigenous science and WMS's knowledge claims, albeit through different knowledge principles and practices; (d) where WMS cannot accept aspects of Indigenous science (e.g., spirituality, animism). This cartography of relations comes to shape if, as well as when and how, Indigenous science is to be included within school science curriculum. Importantly, the degree to which "included" Indigenous science differs from its intended purposes or is deferred through non-inclusion depends highly upon the degree to which it is already articulable within the terms of WMS, as well as science education's ability to ethically respond to difference (from itself). As a result, some forms of Indigenous science "cannot speak" (Kuokkanen, 2008) and remain more "to-come" than others.

It is for this reason that Kuokkanen (2010) states that "the responsibility towards the other must not emerge from hierarchical relations" (p. 69) as these often come to reproduce the very structures of said hierarchy (e.g., here, the epistemic privileging of WMS over other ways-of-knowing-Nature such as TEK and IWLN). Not only do these hierarchal relations potentially produce foreclosure of (the possibility of) knowing otherwise for those who would wish to uphold the hierarchy, but possibly also for those who are critically within and against it (as illustrated 
by my story earlier). The reproduction of such hierarchies of relationships (which also remain on-the-move) is not always a conscious choice; even work founded in best intentions to challenge inequitable relations may come to reify problematic structures. Integrating Indigenous science into an educational programme that has not come to examine the ways in which it (re)produces and is (re)produced by forms of epistemic ignorance runs the risk of (re)producing similar problematics, albeit differently. For example, this can result in enacting pedagogies or curriculum that work towards "'rescuing' the 'other' or knowing what is best for the 'other'" (Kuokkanen, 2010, p. 69). It can also corral Indigenous waysof-living-with-Nature into a (neo-)colonial space of intelligibility without accounting for or be accountable to the ways in which it differs and exceeds such framing. In turn, the work of responsibility towards the ways in which Indigenous science comes to be othered, as well as to-come, in science education requires more than a desire for the relationship to be otherwise if and when the possibility of ethical relationality is (fore)closed by epistemic ignorance.

There is work to be done: work that addresses not only what we do not know, but also how what we know prevents us from knowing what we do not. This is, following Kuokkanen (2007), the homework of responseability.

\title{
The Homework of Response-Ability (Towards Indigenous SCIENCE) in SCIENCE EducAtion
}

\begin{abstract}
Doing homework is an ongoing practice that includes learning as much as possible about the area where the academic takes risks. However, familiarizing oneself with areas one knows little about still amounts to hegemonic practice if we do not engage in the "home" part of the homework.... Homework starts from where we are. (Kuokkanen, 2007, p. 117)
\end{abstract}

As stated, earlier, responsibility is often premised upon the possibility of knowing the other(ness) to which we are responding. But, as the discursive formations of science education often come to foreclose the very possibility of (wholly) heeding such a call (through varying degrees of epistemic ignorance), attempting to know about Indigenous science requires that we engage with, as Kuokkanen (2007) invites, the "'home' 
part of the homework" (p. 117) for it to be more than a "hegemonic practice" through which responsibility becomes response-inability through its enactment (even when the individualistic desire is otherwise). ${ }^{9}$

The "home" part of homework can take many meanings: home as cultural, disciplinary, geographical, historical, epistemological, ontological, among others. However, homework is always risky as it threatens to rupture who we (think we) are, what we (think we) know, and what we (think we) do. Addressing the ways in which the multiplicity of "homes" in homework are (fore)closed when responding to otherness to-come such as Indigenous science is a project that can be unsettling. In part, this is because it asks critical science educators to examine and sit with the ways in which (their) science education practice continues to uphold problematic practices of subsuming, sublating, and suturing over of Indigenous science. Yet, it must bear risk if we are to (re)open responsiveness and the ability to respond to the (constructed) otherness of Indigenous science which is to-come: "responsibility with an inventive rupture implies, first and foremost, the ability of interrupting the self, of moving beyond the 'I' as the ethical subject" (Kuokkanen, 2010, p. 65). Moving beyond the "I" as the ethical subject means considering the ability to respond as being more than individualistic (without excusing the "I" from responsibility): responsibility must be more than a (double(d) practice of) self-accounting for individually doing or having done the right thing. This is a key component of homework. As Kuokkanen (2010) explains, addressing Western modernity as the cultural "home" of science education entails addressing its "worldview of individualism and the notion of the Cartesian subject, [in which] dependency on others is considered a burden" $(2010$, p. 62), as well as the ways in which this comes to shape responsibility. ${ }^{10}$

For science educators, moving beyond the "I" as the ethical subject entails considering the self-in-relation as always already (co-)constituted by vectors of power such as whiteness, Eurocentrism, (neo-)coloniality, modernity, neoliberalism, amidst many others and their respective but irreducibly linked historicities and futurities-to-come, even when working against them. This is all the more important for those who, like me, occupy markers of identity that are privileged by these systems. It is the homework of attending to the ways in which the forces and flows of dominance come to produce the (fore)closure of both self and otherness (making both invisible the normalization of normativity as well as that which lay beyond). Considering the self-in-relation also entails the unheroic work of not assuming that critical pedagogy will always be 
empowering (Ellsworth, 1989), but examining the ways in which this approach may always already be disempowering and prevent participants from responding (from "home"). It is an attempt at a double(d) reversal of the gaze of dominance: a gaze that entails both the literal reversal of studying those who do the studying (i.e., in order to reverse the direction of the gaze), as well as the study of the ways in which those who do the studying study (i.e., in order to reverse the ways in which the gaze is produced and producible).

Yet, while such a double $(\mathrm{d})$ reversal is important, it does not reduce accountability for and towards the other. As mentioned earlier, decolonizing science education must be a movement that creates openings in (neo-)colonial systems and also leverages openings towards making space for honouring Indigenous peoples, places, practices, and priorities. We must still attempt a response within this relation of responsibility, even if response-ability may never be (fully) achieved. Battiste (2005) underscores this (im)possibility using the example of Eurocentrism: "Eurocentrism is not like a prejudice from which informed peoples can elevate themselves" (p. 122). It is for this reason that there is need to reconfigure the normative processes through which we respond and enact responsibility (within the "home" that is science education):

What is more, 'starting from here' involves a subtle but radical shift from 'knowing the other' to learning, and more specifically, learning to receive. Rather than assuming the possibility of knowing the other, we need to learn to think in a fundamentally different way. Instead of thinking that 'we must know' or even 'we are entitled to know'-positions that, by retaining the sense of ownership as well as distance, allow very little room for hospitality...-we need to draw a difference, however provisional, between knowing and learning. (Kuokkanen, 2010, p. 68)

In other words, moving beyond the "I" as the ethical subject entails recognition of the ways in which the Other is always already an irreducible and (co-)constitutive part of the self-in-relation of response-ability. ${ }^{11}$ Rather than the individualistic project of knowing the other (which, as mentioned earlier, cannot be disassociated from forms of epistemic ignorance), we are called to learn from the other (something that requires, by definition, relationality). As Kuokkanen (2010) states, not all learning results in knowing the other: response-ability "requires not only patience but acceptance that there will always be gaps, the 'other' can never be 
fully known" (p. 70). As we learn from the other (recognizing the important, yet subtle distinction between learning about and from), we can learn to learn. Stated otherwise, as we attempt to heed the call of Indigenous science (that is not wholly intelligible as such within the epistemes of science education), we must not only listen, but also listen to how we listen (for the ways in which listening prevents us from hearing). ${ }^{12}$ It is a subtle and attentive movement that necessarily vacillates between knowing and not knowing in order to (re)open the norms of responsiveness in order to not only heed the call of Indigenous science but also work towards hospitably receiving this plurality of diverse Indigenous ways-of-living-with-Nature.

\section{Conclusion: Response-Ability as Moving Within, Against, And Beyond THE (Fore)Closure of EPISTEMic IGNORANCE oR DeCONSTRUCTION AS LEARNING TO LEARN}

Science education always already has a responsibility towards TEK and IWLN; such responsibility precedes its being. ${ }^{13}$ However, it is not always able to enact and uphold this task. As explored within the significant encounter I opened with, the ways in which I became science educator (fore)closed my ability to respond to Indigenous science because I could not heed its call as such. For example, at the time, I could not respond to the ways in which TEK and IWLN are always already more than strictly a human practice that is enacted by the other-than-humans that come to constitute place. My knowledge of what science is was knowledge that acted as epistemic ignorance towards what science could be; specifically, what it always already is and continues to be since time immemorial in the form of TEK and IWLN. There was and continues to unsettle responsibility, in both senses of the word.

In turn, thinking with this experience generated the central question explored throughout: How is the irreducible responsibility that science education has towards Indigenous science to be enacted when Indigenous ways-of-knowing-in-being are made unintelligible, undesirable, and/or invisible through science educations' very systems of thought? This chapter coalesces around the (co-)constitutive relation between knowledge and ignorance (e.g., knowledge-as-ignorance) through Kuokkanen's (2008) conceptualization of epistemic ignorance, such that the inability to 
respond can be framed as rendering unintelligible that which lay beyond epistemic registers, and also inefficacy to account for or be accountable to the ways in which engagement is fraught through the naturalization of said frames. Accordingly, the homework of responsibility through which we labour to transform response-inability into response-ability must entail a (re)opening of the closure through which the other cannot be heard, while simultaneously working to heed the call:

doing one's homework implies unlearning one's privilege and learning... It requires the critical examination of one's beliefs, biases, and assumption as well as an understanding of how they have developed and become naturalized in the first place. (Kuokkanen, 2007, p. 115)

It is important to note that addressing the "home" of homework in attempting to move beyond the (fore)closure of knowledge that is epistemic ignorance is not only deeply productive, but also necessary. Addressing the multiplicitous "home" in the homework of responseability must begin from the ways in which we are shaped by "home" towards its (co-)constitutive exteriority. Kuokkanen (2007) states, as we engage within the very structures that produce epistemic ignorance, this work requires "subtlety and responsibility". Homework that too quickly attempts to evacuate the ways in which we carry "home" elsewhere runs the risk of reproducing the same problems in a new context, albeit slightly differently. Rather, it is important to continue labouring within and against "home" as we attempt the move beyond; to move too quickly to a theory-practice beyond without attending to the "home" of homework runs the risk of as "proceeding in any other way would eventually backfire and merely too tight [ly] reinforce existing structures and discourse [through]... 'irresponsibilizing destruction'" (Kuokkanen, 2007, p. xx). In other words, Kuokkanen (2007) advocates for a deconstructive and critical inhabitation of these structures rather than an attempt to move beyond through their destruction: "the process of decolonization can only emerge from within those structures of domination, from inside" (p. 146). ${ }^{14}$

Deconstruction provides a way out of the (fore)closure of knowledge by (re)opening the interiority to its co-constitutive exteriority, and revealing the ways in which the "philosophical category of the centre (named Eurocentrism)" (McKinley \& Aikenhead, 2005, p. 902) operates. It is to attend to porosity between the two in order to displace, 
disrupt, and decentralize that which was placed with/in (and in turn with/out). As McKinley and her ally Glen Aikenhead state: "deconstruction is the decentralization and decolonization of European thought... Hence, deconstruction is a deconstruction of the concept, the authority, and the assumed primacy of the category of "the West"" $(2005$, p. 902). Deconstruction provides a means of engaging with the interplay of knowing and not knowing that is inextricably linked to epistemic ignorance, as well as the possibility of placing self and other in relations that (re)open the possibility of learning to learn (as opposed to "knowing the other" within the structures afforded). ${ }^{15}$

Importantly, the possibility of hospitably receiving Indigenous science is not only an ethical call. Working to heed the call is ontologically, epistemologically, ecologically, and politically generative: science education stands to learn much from Indigenous ways-of-knowing-in-being and its practices of relational balance, (re)generation, and renewal.

\section{Notes}

1. An earlier version of this chapter appears in Bazzul and Siry's (2019) Critical Voices in Science Education Resesarch (pp. 223-233), and is reprinted with permission.

2. As responsibility is at once necessary yet inadequate, "deconstruction may offer a new way of challenging conventional understandings of responsibility by seeking to move beyond traditional interpretations of politics and ethics" (Kuokkanen, 2007, p. xx).

3. If not in the individual sense, then responsibility is juridical at least in the structural sense. See Chapter 6 for a lengthier discussion on the tie between legal and scientific systems.

4. It is worth latching onto the word attempt, momentarily, as it is significant. It marks an important disjuncture between taking up responsibility and actualizing it that was the deconstructive snag that was used to begin unsettling responsibility (e.g., here, intentionality is often a double(d) settled meaning that is equated with responsible action).

5. As explored within the previous chapter, the question of where to "begin" an inquiry is trouble(d) from its very articulation: with each and every here-now there is a multiplicity of there-thens which are enfolded into its being and becoming. This turn of phrase, to appear in every chapter, serves first to remind the reader that to "begin" as if nothing had been done, what Kuokkanen (2007) refers to as "know-nothing-ism," is its own form of irresponsibility as it has always already begun elsewhere and elsewhen. Second, it is to suggest that because we are already within the 
inquiry, there are many productive junctures with/in which the inquiry can delve into.

Significantly, linking this to problematizing position (rather than positionality) statements, Kuokkanen (2007) offers:

The responsibility of academics [and educators] cannot be limited to neutral descriptions of who we are, as has become common practice at least. In the more self-reflective, critical academic circles; it must also link itself to the concrete, physical locations of our enunciation. (p. 117)

The last part is significant as, for many educators in settler-colonial states (e.g., the US, Canada, Australia), physical location places one in a direct and irreducible relation with Indigeneity (either as someone ancestrally belonging to the place since time immemorial; or as a guest, whether invited or not):

Considering how many universities are located on [I]ndigenous peoples' lands, [I]ndigenous epistemes have always existed in the physical space of the university, however invisible or ignored. Without waiting to be invited, [I]ndigenous epistemes are already "in" the academy. The problem is not how to bring [I]ndigenous knowledge to the university, since it is already there. The problem is the epistemic ignorance that prevails because of the gift of [I]ndigenous epistemes remains impossible within the academy. (p. 108)

Again, this is to say that we are always already within the question of Indigeneity within science education: the somewhere where we "begin," whether a university or other educational institution, is on Indigenous Land and places us firmly in relation. Importantly, as we are already in relation, part of the work is addressing science education's epistemic ignorance which prevents us from recognizing it as such, and in ways that are of consequence to our ways-of-knowing-in-being. "Beginning" somewhere matters (in both senses of the word).

6. While not wanting to reduce this to language, it is important to recognize that the language we possess also possesses us (see Spivak, 1976): language matters in terms of the phenomena we can bear witness to. As David Peat (2002) explains: 
Our [scientific] language disposes us to employ concepts that are entirely inappropriate for the quantum world.... [David] Bohm rejected the idea of a reality composed of objects in interaction in favor of processes and activities in a continuous movement of unfolding and enfolding. Moreover, this reality is not confined to matter but extends to thoughts, feelings, and emotions unfolding within the brain and body. To Bohm there was no dichotomy between inner and outer, mental and physical, subjective and objective, for all are aspects of one underlying movement. The English language [as intended], however, keeps bringing us back to a world of objects. (p. 237)

David Bohm, in his search for a means of accounting for and being accountable to the process, flux, and relationality of quantum phenomena, recognized that these phenomena not only exceeded the enacted practice of science but also the language with which science thought about these phenomena. Bohm's (1980) frustrations with language centred largely around the subject/object binary enacted through much of the English language and its inability to account for contexts which exceed this framing:

The subject-verb-object structure of language, along with its world view, tends to impose itself very strongly in our speech, even in those cases in which some attention would reveal its evident inappropriateness. For example, consider the sentence "It is raining." Where is the "It" that would, according to the sentence, be the "rainer that is doing the raining?" Clearly, it is more accurate to say: "Rain is going on." Similarly, we customarily say, "One elementary particle acts on another," but... each particle is only an abstraction of a relatively invariant form of movement in the whole field of the universe. So it would be more appropriate to say, "Elementary particles are on-going movements that are mutually dependent because they merge and interpenetrate." (p. 37)

For Bohm, language is more than a representational tool that mirrored reality; it is also an enacted enfolding and an unfolding of our epistemologies and ontologies (see also Barad, 2007; Peat, 2002; Spivak, $1993 / 2009)$. Language would then come to shape what was and what was not knowable and do-able, as well as if and how it could come to be. Thus, in order to differently consider and respond to these excessive quantum phenomena, Bohm laboured to envision a hypothetical language that he called the "rheomode" (see Bohm, 1980). 
Stemming from the greek word rheo, meaning to flow, the languageto-come that is the rheomode would have been a language that dealt with processes and activity, transformation and change. This would not only be of use for the quantum phenomena he observed, but also for the interconnected work to which he brought these understandings of process and flux to, such as dialogue and creativity (see Bohm, 1994, 1996). As Peat (2002) explains, the rheomode "is based primarily on verbs and grammatical structures deriving from verbs. Such a language, Bohm argued, is perfectly adapted to a reality of enfolding and unfolding" (p. 238).

However, not unlike Barad (2007), Bohm (1980) states that while the linguistic structures that serve us to quickly describe the macro-world are potentially better served by subject/object language than quantum phenomena, it too is exceeded:

The same sort of description holds on the larger-scale level. Thus, instead of saying, "An observer looks at an object," we can more appropriately say, "Observation is going on, in an undivided movement involving those abstractions customarily called 'the human being' and 'the object he is looking at."' (p. 37)

In taking the double(d) meaning of unsettling seriously, one of most frequent critiques of engaging with the differential configurations of the English language that scholars such as Bohm (1980) and Barad (2007) propose and enact that I continue to encounter is one of unintelligibility. "Why do we need a new language that is so complicated?" some might ask. There is importance in the un/intelligible to push us beyond what we know, how we come to know, and in turn, what we can know. This is not only to differentially become aware of the epistemological and ontological configurations that are always already present within language, but also to (re)open that space, to foster a space of response-ability, a space which allows us to consider otherwise excluded otherness and act in turn.

However, in closing this story (and lengthy footnote), what Bohm had conceived of as a hypothesis and a theoretical language already had lived and long-lasting analogues in place. The similar yet different vocabulary of the "new physics" that stretches the boundaries of Western science was part of the everyday (but differently articulated) vocabulary of Indigenous people:

A few months before his death, Bohm met with a number of Algon[qu]ian speakers and was struck by the perfect bridge between 
their language and worldview and his own exploration of philosophy. What to Bohm had been a more breakthrough in human though - quantum theory, relativity, his implicate order and rheomode - were part of the everyday life and speech of the Blackfoot, [Mi'kmaq], Cree, and Ojibwa[y]. (Peat, 2002, p. 238)

It is potentially the case that Bohm did not know because he could not know if the "lines of making sense" (Spivak, 1993/2009) were laid out such that science, particularly at the time, perceived IWLN as wholly other; but this marks the importance of unsettling settler structures in order to (re)open the space of responsiveness.

7. For Kuokkanen (2007), response-ability requires an ability and willingness to recognize a world beyond oneself. However, and relevant to this story, she cautions that recognition itself must be both an ongoing practice and one that is not isolated from complimentary practices. She states, "recognition cannot be merely an item on a list that, once checked, requires no further consideration" (p. 93), as we often see as the case in practices such as Land acknowledgements at the beginning of events. In these instances,

Recognition can, therefore, also become a proxy for avoiding any responsibility for doing the homework of finding out about things that are unfamiliar - a way of closing the doors and windows rather than granting an unconditional welcome. (p. 91)

Explicitly stated, recognition is always fraught. In taking deconstructive complicity or co-constitution seriously, recognition and misrecognition share an intimate relation:

To recognize someone is always to misrecognize others and render them and their work invisible. Thus, recognizing someone's work ... always involves conforming to certain predetermined norms, that is, to a set of prevailing assumptions about what is worth recognizing. (p. 91)

This is to say that good intentions alone are not sufficient in moves of recognition (even if a willingness to recognize is necessary, an important first step): if practices of recognition cannot be answerable to its own practices (e.g., here, attempting to perceive Indigenous ways-of-knowingin-being through a Western modern scientific worldview), recognition can remain little more than lip service.

8. Further, linking to the previous chapter's discussion of forms of knownothing-ism, ignorance "is not merely an innocent lack of knowledge 
but an intentional not-knowing that serves the economic interests of the status quo" (Kuokkanen, 2007, p. 68). This can be thought of in numerous ways: a refusal (or, softer, a deferral) to learn (despite numerous resources), not taking seriously that which is offered (as a form of epistemic superiority and hubris), or other.

9. Taking seriously the "home" in the "homework of response-ability" includes accounting for and being accountable to our participation in any of the phenomena, scientific or otherwise, that we come to bear witness to. For example, Kuokkanen (2007) invites us to differently consider the problematic relation between Indigenous and Western knowledges systems:

Cultural discontinuity is a consequence, not a cause. It is the result of two things: the willful ignorance that is embedded in the mainstream middle-class culture; and the logic of Eurocentric rationalism, which denies the existence of intellectual conventions and perceptions of the world other than those rooted in the Enlightenment. (p. 54)

Here, there is a clear responsibility. However, there is homework to be done to be able to: first, receive such knowledge; and, second, to respond to and with it.

10. Butler (2005), along these lines rhetorically asks the following: "does the postulation of a subject who is not self-grounding, that is, whose conditions of emergence can never be fully account for, undermine the possibility of responsibility and, in particular, of giving an account of oneself?" (p. 19). Where it is the common assumption that one must "know oneself" (as a stable, containable, and individualistic subject) in order to be morally responsible, Butler (2005) suggests that ethics can only emerge because the "I" of ethics only emerges with/in relation and that a self-contained self becomes a source of "'moral narcissism' whose pleasure resides in its ability to transcend the concrete world that conditions its actions and is affected by them" (p. 105). Relation begets and precedes responsibility; knowledge of a partially knowable self is still, nonetheless knowledge upon which one can act.

11. Along similar lines, Barad (2007) suggests,

There are no individual agents of change. Responsibility is not ours alone. And yet our responsibility is greater than it would be if it were ours alone. Responsibility entails an ongoing responsiveness to the entanglement of self and other, here and there, now and then. $(2007$, p. 394) 
Because of this entanglement, responsibility is not simply a moral imperative but rather an ethico-onto-epistemological enactment that shapes and is shaped by our relational "being-of-the-world." Here, being-of-theworld is a response to Heidegger's being-in-the-world which necessitates an ' $\mathrm{I}$ ' which precedes the relationship with the world, inevitably masking the conditions of emergence for the 'I' which notably only comes to be because there is a world from which it was never separated or separable.

Thus, as Barad (2010) states, responsibility precedes us because it is produced with/in the co-constitutive relationships through which the 'I' of responsibility becomes:

Entanglements are relations of obligation-being bound to the other-enfolded traces of othering. Othering, the constitution of an 'Other', entails an indebtedness to the 'Other', who is irreducibly and materially bound to, threaded through, the 'self'-a diffraction/dispersion of identity. (Barad, 2010, p. 265)

The (Western modern) self does not come to be without an Other; we are always indebted to the inheritance of the other to whom we are with/in relation, regardless of whether this self can or does respond to such responsibility (see Higgins \& Tolbert, 2018).

12. This is to refuse and resist "listening-as-benevolent-imperialism" (Spivak in Harasym, 1990, p. 59), or the ways in which the attempt to listen through dominant frameworks does not always result in hearing. This underscores, as brought up in the preface, the need for a slower crosscultural or decolonizing science education practice that is rife with unsettling pauses.

13. See Chapter 6 for a lengthier exploration of the temporality put forth by this statement.

14. It is not only productively multiplicitous but also, as Derrida (1976) reminds, an inescapable and necessary condition:

The movements of deconstruction do not destroy structures from the outside. They are not possible and effective, nor can they take active aim, except by inhabiting those structures. Inhabiting them in a certain way, because one always inhabits, and all the more when one does not suspect it. Operating necessarily from the inside, borrowing all the strategic and economic resources of subversion from the old structure, borrowing them structurally, that is to say without being able to isolate their elements and atoms, the enterprise of deconstruction always in a certain way falls prey to its own work. (p. 24, emphasis mine) 
There is no outside of "where we are," only the differential ability to respond to the relationality and responsibility that precede and shape us through critical inhabitation in a certain way: active engagement with the norms that structurally and invariably shape our becoming "all the more when one does not suspect it" (Derrida, 1976, p. 24; see also Spivak, 1976, 1993/2009).

Or as scientist Mazzocchi (2006) states on the question of (re)opening possible possibilities within the context of cross-cultural scientific endeavours:

We need to open ourselves to participating in the experience of others, and yet we should also be aware that this opening can only start from where we already are - from our point of view or the tradition to which we belong. (p. 465)

15. In making the case that there are commensurabilities between Indigenous and deconstructive thought, Kuokkanen (2007) speaks to the ways in which deconstruction offers not only a way out of the (fore)closure of epistemic ignorance, but also the closure marked by epistemology itself.

... both $[\mathrm{I}]$ ndigenous thought and deconstructive practice recognize that human existence is embedded in intricate webs that can never be fully grasped either fully or once all... But perhaps it is productive to recognize that deconstructive practices have something to offer [I]ndigenous scholarship, which sometimes tends to ground itself in modernist views rooted in linear reality, and in assumptions that easy access to a neutral truth or the human consciousness is somehow possible. (p. 62)

Without wanting to romanticize deconstruction, as "many theorists of deconstruction are heavily invested in the West's ontological and philosophical traditions" (Kuokkanen, 2007, p. 62), it is productive to engage in with deconstruction in the double(d) movement of unsettling science education (here, deconstructing epistemic ignorance towards its co-constitutive ontology), a topic to be explored in greater depth in the chapters to come. 


\section{REFERENCES}

Barad, K. (2007). Meeting the universe halfway: Quantum physics and the entanglement of matter and meaning. Durham, NC: Duke University Press.

Barad, K. (2010). Quantum entanglements and hauntological relations of inheritance: Dis/continuities, spacetime enfoldings, and justice-to-come. Derrida Today, 3(2), 240-268.

Battiste, M. (2005). You can't be the global doctor if you're the colonial disease. In P. Tripp \& L. J. Muzzin (Eds.), Teaching as activism (pp. 121-133). Montreal, QC: Queen's University Press.

Battiste, M. (2013). Decolonizing education: Nourishing the learning spirit. Saskatoon, SK: Purich Publishing.

Battiste, M., Bell, L., Findlay, I., Findlay, L., \& Henderson, J. (2005). Thinking place: Animating the Indigenous humanities in education. The Australian Journal of Indigenous Education, 34, 7-18.

Bohm, D. (1980). Wholeness and the implicate order. New York, NY: Routledge.

Bohm, D. (1994). On creativity. New York, NY: Routledge.

Bohm, D. (1996). On dialogue. New York, NY: Routledge.

Butler, J. (2005). On giving an account of oneself. New York, NY: Fordham University Press.

Cajete, G. (1994). Look to the mountain: An ecology of indigenous education. Durango, CO: Kivaki Press.

Cajete, G. (2000). Native science: Natural laws of interdependence. Santa Fe, NM: Clear Light Books.

Carter, L. (2004). Thinking differently about cultural diversity: Using postcolonial theory to (re)read science education. Science Education, 88(6), 819-836.

Carter, L. (2010). The armchair at the borders: The 'messy' ideas of borders, border zones and epistemological diversity in multicultural science education. Science Education, 94, 1-20.

Ellsworth, E. (1989). Why doesn't this feel empowering? Working through the repressive myths of critical pedagogy. Harvard Educational Review, 59(3), 297-325.

Harasym, S. (1990). The post-colonial critic: Interviews, strategies, dialogues. New York, NY: Routledge.

Higgins, M. (2014). De/colonizing pedagogy and pedagogue: Science education through participatory and reflexive videography. Canadian Journal of Science, Mathematics and Technology Education, 14(2), 154-171.

Higgins, M. (2017). Post-qualitative mo(ve)ments: Concluding remarks on methodological response-abilities and being wounded by thought. Reconceptualizing Educational Research Methodology, 8(3), 89-101.

Higgins, M., \& Madden, B. (2017). (Not so) monumental agents: De/colonizing places of learning. Canadian Social Studies, 49(1), 34-38. 
Higgins, M., Madden, B., \& Korteweg, L. (2015). Witnessing (the lack of) deconstruction: White teachers' 'perfect stranger' position in urban Indigenous education. Race Ethnicity and Education, 18(2), 251-276.

Higgins, M., \& Tolbert, S. (2018). A syllabus for response-able inheritance in science education. Parallax, 24(3), 273-294.

Kuokkanen, R. (2010). The responsibility of the academy: A call for doing homework. Journal of Curriculum Theorizing, 26(3), 61-74.

Kuokkanen, R. J. (2007). Reshaping the university: Responsibility, Indigenous epistemes, and the logic of the gift. Vancouver, BC: UBC Press.

Kuokkanen, R. J. (2008). What is hospitality in the academy? Epistemic ignorance and the (im)possible gift. Review of Education, Pedagogy, and Cultural Studies, 30(1), 60-82.

Madden, B., \& McGregor, H. E. (2013). Ex(er)cising student voice in pedagogy for decolonizing: Exploring complexities through duoethnography. Review of Education, Pedagogy, and Cultural Studies, 35(5), 371-391.

Mazzocchi, F. (2006). Western science and traditional knowledge. EMBO Reports, 7(5), 463-466.

McKinley, E. (2007). Postcolonialism, Indigenous students, and science education. In S. K. Abell \& N. G. Lederman (Eds.), Handbook of research on science education (pp. 199-226). Mahwah, NJ: Lawrence Erlbaum.

McKinley, E., \& Aikenhead, G. (2005). Comments on "Thinking differently about cultural diversity: Using postcolonial theory to (re)read science education". Science Education, 89(6), 901-906.

Peat, D. (2002). Blackfoot physics: A new journey into the Native American universe. Newbury Port, MA: Weiser Books.

Sammel, A. (2009). Turning the focus from 'other' to science education: Exploring the invisibility of whiteness. Cultural Studies of Science Education, 4, 649-656.

Spivak, G. C. (1976). Translator's preface. In J. Derrida, Of grammatology (G. C. Spivak, Trans., pp. ix-lxxxvii). Baltimore, MD: Johns Hopkins University Press.

Spivak, G. C. (1993/2009). Outside in the teaching machine. New York, NY: Routledge.

Spivak, G. C. (1999). A critique of postcolonial reason. Cambridge, MA: Harvard University Press.

van Eijck, M., \& Roth, W. M. (2007). Keeping the local local: Recalibrating the status of science and traditional ecological knowledge (TEK) in education. Science Education, 91(6), 926-947. 
Open Access This chapter is licensed under the terms of the Creative Commons Attribution 4.0 International License (http://creativecommons.org/licenses/ by $/ 4.0 /$ ), which permits use, sharing, adaptation, distribution and reproduction in any medium or format, as long as you give appropriate credit to the original author(s) and the source, provide a link to the Creative Commons license and indicate if changes were made.

The images or other third party material in this chapter are included in the chapter's Creative Commons license, unless indicated otherwise in a credit line to the material. If material is not included in the chapter's Creative Commons license and your intended use is not permitted by statutory regulation or exceeds the permitted use, you will need to obtain permission directly from the copyright holder.

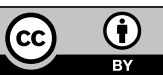

